\title{
Effective Implementation of the Senior High School Curriculum: A Descriptive Analysis
}

\author{
Shiella H. Nacorda \\ M.Ed. Social Science \\ Junior High School Faculty- Social Studies Area \\ University of San Jose- Recoletos
}

\author{
Marcelyn C. Paras \\ MATPE \\ College Faculty- Physical Education \\ Cebu Institute of Technology- University
}

\author{
Conrado D. Diestro \\ M. Ed. \\ Cebu Technological University
}

Josephine N. Olila

MAVEd

Cebu Technological University

Department of Education, Cebu Philippines

\author{
Maricel N. Cogal \\ MA.Ed. \\ University of the Visayas \\ Cebu Technological University
}

\begin{abstract}
The operation of Senior High School Curriculum in the Philippines is faced with different challenges before and after its full implementation; Education sector is making a careful step to ensure perfect execution of the system so that it can help the nation attain its goals. Different styles of assessment, critiquing, debating and reviewing were conducted, in order to eradicate errors in the system. Challenges such as investments on Human Capital, infrastructures, teaching facilities and learning resources or materials were seen as a big factor for ineffectiveness of the system. It has been evaluated in this research review that shortage or absence of such elements in the system will lead to incompetent graduates and failure to execute an effective curriculum. In this research review we enumerated factors that are vital for the system to accomplish its goals and how these elements may be a hindrance in achieving our goals as a nation.
\end{abstract}

Keywords- K-12 Curriculum, Human Capital, Education Sector, Senior High School Curriculum.

\section{INTRODUCTION}

The Department of Education in the Philippines implemented the Enhanced Basic Education Curriculum in 2013 which led to the creation of Senior High School Program (Estonanto, 2017). Education plays an important role in the lives of the students and for the society. A responsive and productive citizen are essential element to promote development, therefore education sector in the Philippines must be aware of crucial steps to take in order to produce graduates that are not only focused on themselves but are responsive to the needs of the society. This K-12 curriculum introduced new pattern of systems for the Philippine education sector. Human capital, infrastructures, grading system and managing system in a school are now assessed in order to develop an effective curriculum, shaped to produce responsive individuals for the society.

Education has its purpose on how an individual face the world. It idealizes different kinds of society and different types of individual. We change people by educating them the knowledge, by helping and guiding them to develop new insights, sense of values and abilities (Orimaco T. S., 2000). It is a task for the government to initiate more development in order for the teachers to help the students develop their talents, formulate good values that will help them in day to day living and discover new abilities through activities that are conducted in the classroom. With the new trends of education, implementation of the Senior High School curriculum provided an avenue to enhance and develop more skills for our graduates to become an expert to their field and become an agent of change in the society.

Senior high school implementation aimed to equip the students with essential knowledge and skills that will help them prepare better for the chosen path in the higher education, employment, or entrepreneurship. The addition of two more years or two more grade levels, Grades 11 and 12 , will better equip the students with the necessary skills, knowledge, and values needed for a successful future in their fields or course.

On the other hand, implementation of this curriculum faces different problems that need to be addressed. These problems are part of the growth process of the curriculum. This research review will provide us information that will help us to evaluate and critically assess the dilemmas faced by the SHS curriculum in the Philippines. The challenges faced by Senior High School Curriculum in the Philippines are also information that will help us evaluate its level of effectiveness.

\section{OBJECTIVES OF THE STUDY}

This research review aims to stand as an assessment item for the implementation of Senior High School in the Philippines. Specifically, this research review seeks to understand the following areas:

1. Determine areas of difficulty in implementing SHS in the Philippines; 
2. Identify areas that will require immediate plan of action to deliver effective and efficient SHS system in the Philippines;

3. Propose intervention to provide effective system in implementing SHS in the Philippines.

\section{METHODOLOGY}

This is a descriptive research which utilizes data from reliable web portals, topical and latest published research materials. It analyzes the different data to determine connections of different issues and challenges in the implementation of Senior High School Curriculum in the Philippines.

The content of this paper also utilized related studies and review of related literature as a source of reference in finding knowledge and information that response all the questions of this paper. In addition, this paper identifies different areas that will come up with immediate plan of action to deliver effective and efficient Senior High School system in the Philippines.

\section{PRESENTATION OF DATA AND ANALYSIS}

The K-12 curriculum in the Philippines is outlined to create more developments and alleviate social issues, the first batch of students and graduates for this curriculum were expected to experience the formation of fundamental elements which will stand as the formators of standards and development stage for different assessments which will serve as a tool to initiate more development for the next years to come. The following discussions were analysis from different data gathered to describe the procedures taken to implement an effective senior high school curriculum in the Philippines.

\section{A. Implementation of the Senior High School Curriculum}

The implementation of the $\mathrm{K}$ to 12 Basic Education Program in the Philippines includes the introduction of senior high school (SHS), or grades 11 and 12, the final 2 years in a new 6-year secondary education system (Asian Development Bank, n.d.). The Philippine Government has partnered with the Asian Development Bank (ADB) through the Senior High School Support Program (SHSSP) to support the full implementation of the Senior High School (SHS) Program of the $\mathrm{K}$ to 12 Basic Education reform (DepEd, 2014).

The Philippines has now a total of 13 years from Kindergarten to Grade 12, all of which are mandatory and free especially in the public schools. It even subsidizes students who will take their grade 11 to 12 classes in the private schools or universities/colleges through the voucher program (Sarmiento \& Orale, 2016). Students are required to choose their preferred senior high strands as prerequisite for College admission.

Senior High School is two years of specialized upper secondary education; students may choose a specialization based on aptitude, interests, and school capacity. The choice of career track will define the content of the subjects a student will take in Grades 11 and 12. SHS subjects fall under either the Core curriculum or specific tracks (What is K-12 Program)

Upon enrollment in senior high school, students are going to pick among four senior high strands or tracks. To select a right strand is one of the important assertions a student must have in the Philippines in order to acquire basic skills and knowledge needed for their college course (Enderun Colleges, 2019). Students will undergo assessments to determine their strengths and interests to guarantee a good decision for their Senior High School strand preference. These will include an aptitude test, a career assessment exam, and an occupational interest inventory for high schools. Career advocacy activities will also be conducted to help guide students in choosing their specialization or track (What is K-12 Program)

Curriculum Guides were also distributed to Senior High School Teachers to use as a tool for teaching instructions based on standards. Senior High School teachers were also given essential trainings, workshops and seminars to be fully equipped with vital information in molding senior high school students ready for work or to continue higher education. Administrative positions in the Philippine education sector were also guided through DepEd Memorandum no. 76 series of 2016, in this memorandum a manual is intended to be circulated and be of use to ensure standards and help school heads to of Senior High School in the Philippines to carry out necessary preparations before the opening of classes (Department of Education, 2016).

Senior High School Curriculum together with the Department of Education in the Philippines aims that the graduates will acquire essential skills that will provide them work opportunities to different sectors in the society (Department of Education, 2016), which serves as a respond to the plea of most non-graduate Filipino citizen.

\section{B. Challenges and issues in the Implementation of the SHS curriculum}

Issues were revealed during the process of implementation of SHS curriculum in the Philippines, however despite of different issues and challenges it was not enough to suspend its application to fully operate SHS curriculum. These are the following challenges exhibited during the course of full implementation of Senior High School in the Philippines.

It is well recognized that growth in education are associated with long-term improvements in economic performance (Combalicer, 2016). These improvements therefore can manifest effective implementation of the program if provided. According to Combalicer in his research that there are three broad assumptions presented on how education influences economic performance: 1 . The innovation approach; 2. The Human Capital as investment and 3. Knowledge- Transfer Approach (Combalicer, 2016).

It is seen that the SHS-tracks to be offered in different areas will be based on the availability of resources in in the area (What is K-12 Program); This scenario provides limitations to students who belong to areas that have less resources to support different tracks or specializations in which they are most capable of. This will lead some students to be enrolled in other areas which will require them more 
necessities for their SHS education, or it will result for them to be forced enrolled in a SHS-track that these students may either be capable or less capable for the track. A mismatch might be an end result for this scenario. This idea describes innovation approach wherein graduates and the system should finance innovations in order to acquire required materials for instructions and to create a productive and efficient system.

In a study analysis presented by Development Asia, it listed different issues that may constrain a school's general operations. School's operational system confronted with the following 1. inadequacy of facilities $(43.1 \%)$, 2. lack of teachers $(28.6 \%)$, and 3. application requirements to be able to offer different SHS tracks (17.5\%) (Asian Development Bank, n.d.). Private schools on the other hand were mainly constrained by the lack of student demand or enrollment (32.9\%), application requirements to be able to offer different SHS tracks (13.2\%), and inadequacy of facilities (12.7\%) (Asian Development Bank, n.d.). This scenario describes that the system needed to think and re-think Human Capital investment in order to function as a perfect system gearing to attain a goal. The data presented form the Development of Asia also displays a need to innovate in order to supply inadequacy of facilities. A long existence in a system with the following data may function ineffectively since it does not provide necessities that will help the system operate effectively.

Time is another detail of inconvenience during the formation period of the senior high school system, they needed to train teachers to be qualified to teach in senior high school and other managing system intended for senior high school environment; assigning mismatched group of human capital may result to low performance for senior high school students, which means they will not be globally competitive and may not provide adequate assistance to provide solutions to different social issues in the Philippines, this challenge was shared by an online news, which describes and states that DepEd is truly experiencing lack of teachers and valuable personnel to be trained for senior high school (Ciriaco, 2018).

Due to the dilemma of insufficient number of human capital for senior high school; Mass hiring and nationwide mass trainings and series of orientation were held before the course of full implementation for the new curriculum and with this activity, more funds were needed that caused delays for other financial assistance which might be intended for infrastructures meant for senior high school students population to use, DepEd admits such issues through an online sunstar news (Llanes, 2018). Having a more educated workforce enables firms to take advantage of new economic opportunities, leading to improved performance (Combalicer, 2016), investing on human capital is a requirement for an institution to perform well.

Lack of buildings and workshop rooms for specific strands were not fully provided for senior high school in public schools even the private sector were experiencing a struggle in acquiring needed number of rooms, buildings and laboratories intended for the different strands as shared and described in the study given by the Development Asia and sponsored by Asian Development Bank.

\section{Descriptive Analysis of Effectiveness of Senior High} School Implementation

The number of challenges faced by the senior high school curriculum during the years of its structural development and with its full term, can be considered an item to manifests a struggle to effectively implement the curriculum. Some of essential resources and workforce in executing the curriculum were still in the process of acquiring it, both public and private sector experiences a struggle in providing materials needed for teaching sessions.

It has been expressed by most educators that teaching aids are essentials in achieving various learning goals for senior high school curriculum, thus it expresses ineffectiveness if it is not provided. Elpidius Melunga in his research review states the importance of teaching aids for this will allow students the opportunity to achieve mastery of content (Melunga) and therefore attain learning goals as expressed in the curriculum.

As shared from an article Serious Problems with the K-12 Senior High School Curriculum of Joel Tabora, that Fr. Inocensio explained that the senior high school "core curriculum" requirement is so demanding that there would be no time to develop applied skills for the students to learn such as the manufacturing industry requires (Tabora, 2014). It was described from Tabora's article that senior high school curriculum is over-congested and that there is a need to reassess and reevaluate the list of subject offered for different Senior High School tracks to certify credibility of the graduates that they are equipped with skills that can respond the demands of the labor force. This scenario if not properly given attention to, the main purpose of a job-ready individual may not be acquired after graduation, thus it implies ineffectiveness of the system based on expected output of the system.

An online article by Rev. Fr. Antonio Cecilio T. Pascual shared the study of Philippine Business for Education, that even most of the senior high school students are ready to work, the market is not as prepared to receive or employ them (Rev. Fr. Pascual, 2019). This scenario is also highlighted by Kath M. Cortez on her article in Davao Today, according to this article "Labor Official: Few Companies Hire Senior High Graduates" , that labor groups confirmed the idea that few companies in Davao City offer job for senior high school graduates despite the assurance from the Department of Education (DepEd) that the $\mathrm{K}$ to 12 program will equip students with values, knowledge and skills needed to work in various industries (Cortez, 2019). The business sector in the Philippines is not supporting the transformation. It is also described that few interventions from the government are presented to ensure productive senior high school graduates. If this will continue, the system will not be effective if the senior high school graduates cannot penetrate in the business sector as part of labor force, the existence of the system lacks to support its goal and main function in the society, therefore such scenario can stand as factor for its ineffectiveness. 


\section{CONCLUSIONS}

K-12 curriculum in the Philippines is under a series of observation, different details in this curriculum are scrutinized to test its importance in the system. The success of a system is dependent to different factors, if neglected will result to another social issue; After several readings of different data, examined, investigated and interpreted, it can be concluded that:

1. There is an existing level of difficulty in providing required skills, demanded by the different working industries due to deficiency of infrastructures which can accommodate Hands-on Learning;

2. Education sector in the Philippines, lack financial support to invest more on their Human Capital and for essential infrastructures intended for workshops rooms or laboratories;

3. Business sectors are skeptical in hiring senior high school graduate, therefore a work-ready graduate for senior high school graduate is not achieved;

4. On the Job-training of students from public schools are not well supported by business sectors;

5. There is a need to review learning guides or curriculum guide for Senior High School, since it displayed a congested curriculum and experiencing deficiency of time for hands-on learning activity;

6. There were few valid forms of assessment of the level of effectiveness of senior high school system.

\section{VI . RECOMMENDATIONS}

After a series of assessment, analysis and reviewing different research content this research review paper would like to recommend the following:

1. Request assistance from different Non-Government Organization and generous stakeholders to resolve issues on inadequacy of important infrastructures and learning materials;

2. Education sector should assist schools in creating affiliations with different business sectors to formulate agreements that will allow senior high school students conduct On- the Job Training opportunities;

3. Philippine Government should create initiative for private business sectors to invite senior high students for hands-on learning sessions or On-the Job training opportunities and incentives for hiring a senior high school graduate;

4. Education sector should develop more assessment program to develop an impeccable curriculum guide for senior high school;

5. Endorse more form of assessments to measure level of effectiveness for the senior high school system.

\section{ACKNOWLEDGMENT}

The authors would like to express gratitude to Dr. Marilyn M. Miranda for giving us the opportunity to explore more to our profession, for encouraging us to research, write and publish. To our family who supported us by giving us the time to work and to stay focus for this research. To our colleagues who are willing to offer assistance and provide answers to our queries and most of all to God Almighty who gave us the strength and knowledge to deliver the task well and provide valuable information for the society.

\section{REFERENCES}

[1] Asian Development Bank. (n.d.). Development Asia. Retrieved November 30, 2019, from Development. asia: https://development.asia/insight/factors-affecting-senior-highschool-track-offerings-philippines

[2] Ciriaco, C. M. (2018, June). Business Mirror. Retrieved October 2019, from https://businessmirror.com.ph/2018/06/04/classroomteacher-shortages-hound-schools-but-deped-says-theyre-butchallenges/

[3] Combalicer, L. F. (2016, June). BEST PRACTICES AND PROBLEMS IN THE INITIAL IMPLEMENTATION OF THE K+12 CURRICULUM AMONG THE TEACHERS IN INFANTA, QUEZON: IMPLICATIONS TO AN EFFECTIVE IMPLEMENTATION OF SENIOR HIGH SCHOOL. Journal of Education and Social Sciences, 4, 3. Retrieved November 28, 2019 , from https://www.jesoc.com/wp-content/uploads/2016/08/Edu-4

[4] Cortez, K. M. (2019, June 18). Davao Today. Retrieved from Davao Today. com: http:// davaotoday.com

[5] Department of Education. (2016, May 6). deped.gov.ph. Retrieved December 1, 2019, from https://www.deped.gov.ph/wpcontent/uploads/2018/10/DM_s2016_076.pdf

[6] DepEd. (2014). Department of Education. Retrieved 2019, from DepEd.gov.ph: https://www.deped.gov.ph/k-to-12/senior-highschool/the-senior-high-school-support-program/

[7] Enderun Colleges. (2019). Retrieved October 2019, from https://www.enderuncolleges.com/senior-high-strand/

[8] Estonanto, A. J. (2017). Acceptability and Difficulty of the STEM Track Implementation in Senior High School. Asia Pacific Journal of Multidisciplinary Research, 5(2), 43-50. Retrieved December 1, 2019, from http://www.apjmr.com/wpcontent/uploads/2017/04/APJMR-2017.5.2.05

[9] Llanes, J. (Ed.). (2018, March 25). Sunstar. (Sunstar) Retrieved October 2019, from sunstar.com.ph: https://www.sunstar.com.ph/article/1502549

[10] Melunga, E. (n.d.). Academia. Retrieved 2019, from Academia.edu.com: https://www.academia.edu/11510050/TEACHING_AND_THE_IM PORTANCE_OF_TEACHING_AIDS

[11] Officialgazette.gov.ph. (n.d.). Retrieved October 23, 2019, from GOV.PH: https://www.officialgazette.gov.ph/k-12/

[12] Orimaco, T. S. (2000). Career Motivational Factors, Attitudes, Performance, and Problems of Students toward Physical Education Course. Cebu City

[13] Orimaco, T. S. (2000). Career Motivational factors. Attitudes Performance and Problem of Students toward Physical Education Courses.

[14] Rev. Fr. Pascual, A. C. (2019, February 1). Business Mirror Retrieved November 20, 2019, from Business Mirror.com.ph. https://businessmirror.com.ph

[15] Sarmiento, D. H., \& Orale, R. L. (2016). Research Gate. Journal of Academic Research, 1. Retrieved October 5, 2019, from Research Gate.

https://www.researchgate.net/search?q=senior\%20high\%20school\% 20curriculum\%20in\%20the\%20Philippines

[16] Tabora, J. S. (2014, February 18). Academia. Retrieved from Academia: https://www.academia.edu/28440538/Serious_Problems_with_the K-12_Senior_High_School_Curriculum 